\title{
ISOLATION AND CHARACTERIZATION OF BACTERIAL SPECIES FROM ENTERIC FEVER SUSPECTED HUMAN CASES OF MYMENSINGH MEDICAL COLLEGE HOSPITAL
}

\author{
M. Al-Amin, M. S. R. Khan*, F. Begum¹, J. Hasan and M. Asaduzzaman² \\ Department of Microbiology and Hygiene, Bangladesh Agricultural University \\ Mymensingh-2202, Bangladesh
}

\begin{abstract}
A total of 17 stool samples were collected from enteric fever suspected patients of Mymensingh Medical College Hospital, Mymensingh, Bangladesh. Results of morphological, biochemical examinations and pathogenicity test revealed Escherichia coli (47\%), Klebsiella spp. (41\%), Citrobacter spp. (29\%). In cultural examination, all Escherichia coli showed metallic sheen on EMB agar, Klebsiella spp. showed moist shiny mucoid colonies and Citrobacter spp. showed large convex colorless dwarf colonies on MacConkey agar. In biochemical examination, all the isolates fermented five basic sugars with the production of acid and gas where the Citrobacter spp. were late lactose fermenter. Escherichia coli was indole and MR positive but V-P negative, Klebsiella spp. were V-P positive but MR and Indole negative and Citrobacter spp. were MR positive but $\mathrm{V}-\mathrm{P}$ and Indole negative. All isolated bacterial species were sensitive to ciprofloxacin but resistant to amoxicillin. Salmonella typhi or Salmonella paratyphi organisms were not present in the stool samples examined. This may be due to collection of samples from patient having antibiotic therapy with Ceftriaxone through intravenous route for 3 days prior to collection of samples. From this study, it may be concluded that Escherichia coli, Kelbsiella spp. and Citrobacter spp. may be commonly present in enteric fever suspected patients or they may produce enteric fever like symptoms in human.
\end{abstract}

Key words : Enteric fever, Isolation, Characterization, Bacterial species, Antibiotics

\section{INTRODUCTION}

Enteric fever refers to enteric illnesses of human caused by Salmonella enterica (S. enterica) serovars typhi and paratyphi A, B and C (Crump et al., 2004) under the family Enterobacteriaceae. It is a gastrointestinal condition mainly in the developing world usually as a form of food poisoning. Both typhoid and paratyphoid are collectively called 'enteric fever', (Levine et al., 1983) that causes a generalized infection of the

\footnotetext{
${ }^{1}$ Livestock Research Institute, Mohakhali, Dhaka, Bangladesh

2 Department of Pathology, Bangladesh Agricultural University, Mymensingh-2202, Bangladesh

* Correspondence E-mail :- msrkhan001@yahoo.com
} 
reticuloendothelial system and endothelial cells accompanied by sustained fever and bacteremia which encompasses a range of severity with typhoid to the severe and paratyphoid to the milder parts of the spectrum. In most endemic areas, approximately $90 \%$ of enteric fever is typhoid (Parry, 2006). Serovar paratyphi A is the second most prevalent cause of typhoid responsible for one third of cases or more in southern and eastern Asia (McClelland et al., 2004). The incubation period of enteric fever may be as long as 3 weeks following ingestion of the infectious dose of organisms (Gutherie, 1991).

Some other enterobacterial species along with S. enterica serovars typhi and paratyphi can be demonstrated from enteric fever infected or suspected patients. These include Escherichia coli (E. coli), Shigella spp, Klebsiella spp., Citrobacter spp., Enterobacter spp., Proteus spp., Serratia spp. etc.

The global emergence of multidrug-resistant (MDR) strains and of strains with reduced susceptibility to fluoroquinolones is of great concern (Bhan et al., 2003). There are about 16 million cases a year which result in about 25,000 deaths worldwide (Rubin et al., 2007). In Bangladesh many people affected with typhoid and paratyphoid each year. The incidence rate of enteric fever in central and south Asia is estimated at more than 100 cases $/ 100,000$ population per year with the highest burden of disease seen in children. The incidence of typhoid is higher in 0-4 age groups and male are more susceptible than female (Freeman, 1985). Typhoid first reported in Bangladesh in 1986 and Pakistan in 1988 and is currently endemic in South Asia (Morshed et al., 1986).

The confirmatory diagnosis requires isolation and characterization of the causal agents from suspected cases and cultural, morphological, biochemical and serological examinations. Control measures required treatment with antibiotics and vaccination. Major treatment of enteric fever includes ciprofloxacin for ten days or ceftriaxone/ cefotaxime for 14 days or azithromycin for seven days (CDC, 2001). Thus the present work was designed to isolate and characterize the bacterial species from enteric fever suspected human cases and as well as to evaluate the antibiogram.

\section{MATERIALS AND METHODS}

The experiment was conducted from January, 2009 to November, 2009 in the Bacteriology laboratory of the Department of Microbiology and Hygiene, Bangladesh Agricultural University, Mymensingh.

\section{Laboratory and specimens}

A total of 17 stool samples from enteric fever suspected patients of Mymensingh Medical College Hospital were tested for the examination.

\section{Cultivation, biochemical characterization and isolation of bacterial species}

Stool samples were collected and immediately brought to the Bacteriology laboratory, grown into Nutrient broth by incubating at $37^{\circ} \mathrm{C}$ for 24 hours aerobically. From the 
Nutrient broth it was then cultured onto different cultural meadia such as Nutrient agar, Blood agar, Salmonella-Shigella (SS) agar, MacConkey agar and Eosin Methylene Blue (EMB) agar to study the cultural characteristics of the organisms. Then morphological, biochemical examinations and pathogenicity test of the isolates were performed (Merchant and Packer, 1976; Cheesbrough, 1985) to identify the organisms present in the stool of enteric fever suspected human patients.

\section{Motility test}

The motility test was performed according to the method described by Cowan (1985) to differentiate motile bacteria from the non-motile one. Before performing the test, a colony of pure culture was allowed to grow in NB. One drop of cultured broth was placed on the cover slip and placed inverted over the concave depression of the hanging drop slide to make hanging drop preparation. Vaseline was used around the concave depression of the hanging drop slide for better attachment of the cover slip to prevent air current and evaporation of the fluid. The hanging drop slide was then examined carefully under 100X objective of a compound light microscope using immersion oil. The motile and nonmotile organisms were identified by observing motility in contrasting with movement of bacteria.

\section{Pathogenicity test}

On the basis of the statement of Merchant and Packer (1976) on pathogenicity test, day old white suckling and adult female mice were used to observe the entero-pathogenicity of the isolated bacterial species. In this experiment, 23 mice were divided into 21 groups where each group contain one mouse including control group. For inoculation into mice, a single colony of each isolate of enteric bacterial species were added to the $5 \mathrm{ml}$ of NB. The broth was then incubated at $37^{\circ} \mathrm{C}$ for 24 hours aerobically and determined colony forming unit (CFU) per $100 \mu \mathrm{l}$ as per standard protocol. A dose of $250 \mu \mathrm{l} /$ mouse (200 $\mathrm{CFU} / 100 \mu \mathrm{l}$ ) of culture was given to mice orally. Control group consisting of one mice were inoculated with sterile nutrient broth.

Another 8 mice of 45 to 60 days-old were divided into 8 groups where each group contain one mouse including control group and $1 \mathrm{ml}((200 \mathrm{CFU} / 100 \mu \mathrm{l})$ of 7 isolates of Klebsiella were injected though intragastric route. All the mice were kept isolated and under observation for 4 days. Mice that died during observation period were subjected to postmortem examination in order to reisolate the organism.

\section{Antibiogram study of isolated bacterial species}

Susceptibility of the isolated bacterial species to different antibacterial agents was performed through disc diffusion method (Bauer et al., 1996). In this method isolated bacterial species were grown overnight on selective agar. The overnight cultured isolates were inoculated into Nutrient Broth and poured on Nutrient Agar or other selective agar and spread uniformly with the help of sterile glass spreader. Antibacterial disc were 
applied aseptically to the surface of the plate at an appropriate arrangement with the help of sterile forceps and incubated aerobically at $37^{\circ} \mathrm{C}$ for 24 hours.

\section{Maintenance of stock culture}

Bacterial species isolated from enteric fever suspected human patients were preserved in agar slant method, $80 \%$ buffered glycerin and soft agar method.

\section{RESULTS AND DISCUSSION}

Salmonella enterica serovars typhi and paratyphi A, B and C are the actual causal agents of enteric fever but some other enterobacterial species are associated from enteric fever suspected and/or infected human cases. Out of 17 stool samples examined, 8 (47\%) were positive for E. coli, 7 (41\%) for Klebsiella spp. and $5(29 \%)$ for Citrobacter spp.

In this study, all Escherichia coli (E. coli) produced metallic sheen while Klebsiella spp. produced large moist, shiny, mucoid, more watery pale red colony with dark red and Citrobacter spp. produced large, circular, smooth surface, pale red colonies on EMB agar. On MacConkey agar E. coli produced large, smooth, round, dull, opaque and low convex rose pink colored colony while Klebsiella spp. produced large, moist, shiny, mucoid, convex pink color colony and Citrobacter spp. produced large, moderately convex with an entire edge colorless and dwarf colonies. On SS agar, E. coli produced pinkish circular small colony where as the Klebsiella spp. produced small, slight growth, pink colony with pink red precipitation of the medium and Citrobacter spp. produced small blackish colony with pink red precipitation of the medium. In Gram's staining, all E. coli and Citrobacter spp. were Gram-negative, pink colored, medium rod shaped and arranged in single or paired. All isolated Klebsiella spp. were Gram-negative, pink colored, large bacilli and arranged in single. Among all isolated bacterial species, Klebsiella spp. were found to be non-motile and E. coli and Citrobacter spp. were found to be motile when examined using hanging drop slide under microscope.

The present study showed colony growth characters of E. coli on EMB and MacConkey agar exhibited characteristic reaction which relates to the findings of Ali et al. (1998). On the other hand colony growth characters of Klebsiella spp. and Citrobacter spp. on EMB agar, MacConkey agar and SS agar also showed remarkable characteristic pattern which were similar to the findings of the other authors such as Cheesbrough (1985); Wong et al. (1985); Bagley et al. (1978); Sghau et al. (1958); Bergan (1984) respectively. In Gram's staining, the morphology of isolated bacterial species was supported by Thomas et al. (2005) and Freeman (1985) for E. coli, Ryan et al. (2004) for Klebsiella spp. and Cheesbrough (1985) for Citrobacter spp. 
In biochemical test all isolates fermented 5 basic sugars with the production of acid and gas except late lactose fermenter Citrobacter spp. (Table 1). E. coli isolates were MR and Indole positive where as Klebsiella spp. were V-P and Citrobacter spp. were MR positive. In TSI agar slant reaction E. coli and Klebsiella spp. exhibited Yellow slant and yellow butt Citrobacter spp. showed red slant and yellow butt (Table 1) which was described earlier (Chessbrough, 1985). The results of MR, V-P and Indole test of E. coli, Klebsiella spp. and Citrobacter spp. strongly support the findings of Ali et al. (1998); Thomas et al. (1998); Buxton and Fraser (1977); Cheesbrough (1985).

Table 1. Biochemical reactivity patterns of isolated bacterial species

\begin{tabular}{|c|c|c|c|c|c|c|c|c|c|}
\hline \multirow[t]{2}{*}{ Isolates } & \multicolumn{5}{|c|}{$\begin{array}{l}\text { Fermentation of } 5 \text { basic sugars with } \\
\text { the production of acid and gas }\end{array}$} & \multirow[t]{2}{*}{$\begin{array}{l}\text { MR } \\
\text { test }\end{array}$} & \multirow[t]{2}{*}{$\begin{array}{l}\text { V-P } \\
\text { test }\end{array}$} & \multirow[t]{2}{*}{$\begin{array}{c}\text { Indole } \\
\text { test }\end{array}$} & \multirow[t]{2}{*}{$\begin{array}{l}\text { Reaction in TSI agar } \\
\text { slant }\end{array}$} \\
\hline & DX & ML & $\mathrm{L}$ & $S$ & $\mathrm{MN}$ & & & & \\
\hline E. coli & \multicolumn{5}{|c|}{+} & + & - & + & $\begin{array}{l}\text { Yellow slant (AR) } \\
\text { Yellow butt (AG) }\end{array}$ \\
\hline Klebsiella spp. & \multicolumn{5}{|c|}{+} & - & + & - & $\begin{array}{l}\text { Yellow slant (AR) } \\
\text { Yellow butt (AG) }\end{array}$ \\
\hline Citrobacter spp. & \multicolumn{5}{|c|}{+ but late lactose fermentation } & + & - & - & $\begin{array}{l}\text { Red slant (AkR) } \\
\text { Yellow butt (AG) }\end{array}$ \\
\hline
\end{tabular}

Legends $: \mathrm{AR}=$ Acid reaction, $\mathrm{DX}=$ Dextrose, $\mathrm{ML}=$ Maltose, $\mathrm{L}=$ Lactose, $\mathrm{S}=$ Sucrose, $\mathrm{MN}=$ Mannitol, AG = Acid and Gas, MR = Methyl Red, V-P = Voges-Proskauer, + = positive, - = Negative

In pathogenicity test, all isolates were administered orally into female mice and all E. coli and Klebsiella spp. inoculated mice were died within 18 to 48 hours of administration but Citrobacter spp. administered mice were died after 30 hours. On the other hand, another group which was injected through intragastric route with each of 7 Klebsiella spp. were died within 22 to 48 hours of injection. On post-mortem examination, gross pathological lesions were observed in almost all the dead mice. The mice those died comparatively earlier revealed the congestion of blood vessels. In most cases, pin point hemorrhage and congestion was commonly observed in liver, lung, kidney and intestine. In Kelbsiella spp. injected mice, there was remarkable congestion in lung, liver and heart muscle. The liver discolored to black and the lung showed the sings of pneumonia. The present findings were supported by the findings of Cogen and Moore (2009); Bleich et al. (2008).

Comparative antibiogram results of E. coli, Klebsiella spp. and Citrobacter spp. were summarized in Table 2. All isolated bacterial species from enteric fever suspected patients were found to be sensitive to ciprofloxacin and resistant to amoxicillin.

The antibiogram study of E. coli supports the finding of Ameh et al. (2003); Jordi et al. (1999); Chowdhury et al. (1994); Klebsiella spp. supports the finding of Stock and Wiedemann (2001) and Citrobacter spp. supports the finding of Barger et al. (2002). 
Table 2. Comparative antibiotic sensitivity pattern of isolated bacterial species

\begin{tabular}{|c|c|c|c|c|c|c|c|c|c|}
\hline \multirow[t]{3}{*}{ Disc } & \multicolumn{9}{|c|}{ Sensitivity analysis (\%) } \\
\hline & \multicolumn{3}{|c|}{ E. coli } & \multicolumn{3}{|c|}{ Klebsiella spp. } & \multicolumn{3}{|c|}{ Citrobacter spp. } \\
\hline & S & IS & $\mathrm{R}$ & $S$ & IS & $\mathrm{R}$ & $S$ & IS & $\mathrm{R}$ \\
\hline CIP & 100 & 0 & 0 & 43 & 57 & 0 & 80 & 20 & 0 \\
\hline $\mathrm{C}$ & 100 & 0 & 0 & 29 & 57 & 29 & 60 & 10 & 0 \\
\hline AML & 0 & 0 & 100 & 0 & 0 & 100 & 0 & 0 & 100 \\
\hline CL & 0 & 0 & 100 & 0 & 0 & 100 & 40 & 20 & 40 \\
\hline$W$ & 63 & 25 & 13 & 0 & 43 & 57 & 40 & 40 & 20 \\
\hline CE & 38 & 0 & 63 & 0 & 28 & 71 & - & - & - \\
\hline $\mathrm{TE}$ & 50 & 38 & 13 & 29 & 57 & 14 & 40 & 60 & 0 \\
\hline $\mathrm{CN}$ & 63 & 0 & 38 & - & - & - & 80 & 20 & 0 \\
\hline $\mathrm{AZM}$ & - & - & - & 43 & 43 & 14 & 80 & 20 & 0 \\
\hline $\mathrm{E}$ & - & - & - & 29 & 71 & 0 & 80 & 20 & 0 \\
\hline
\end{tabular}

Legends : $\mathrm{S}=$ Sensitive, IS = Intermediately Sensitive, $\mathrm{R}=$ Resistant, $\mathrm{CIP}=$ Ciprofloxacin, $\mathrm{C}=$ Chloramphenicol, $\mathrm{AML}=$ Amoxicillin, $\mathrm{CL}=$ Cephalexin, $\mathrm{W}=$ Trimethoprim, $\mathrm{CE}=$ Cephradine, $\mathrm{TE}$

$=$ Tetracycline, $\mathrm{CN}=$ Gentamicin, $\mathrm{AZM}=$ Azithromycin, $\mathrm{E}=$ Erythromycin,$-=$ Not done

\section{CONCLUSION}

Salmonella typhi or Salmonella paratyphi organisms were not present in the examined stool samples. This may be due to collection of samples from patient having antibiotic therapy with Ceftriaxone through intravenous route for 3 days prior to collection of samples. From this study, it may be concluded that Escherichia coli, Kelbsiella spp. and Citrobacter spp. may commonly present in enteric fever suspected patients or they may produce enteric fever like symptoms in human.

\section{REFERENCES}

Ali, M. Y., Rahman, M. T., Islam, M. A., Choudhury, K. A. and Rahman, M. A. 1998. Characteristics of E. coli isolates of human and animal origin. Progress. Agric. 9(1\&2): 221-224.

Ameh, E. A. 2003. Perianal abscess and fistula in children in Zaria. Niger postgrad Med, J., 10: 107-9.

Bagley, S. T. and Seidler, R. J. 1978. Primary Klebsiella Identification with MacConkey-InositolCarbenicillin Agar. Applied Environ. Microbiol., 36(3): p. 536-538.

Bauer, A. W., Kirdy, W. M. N., Sheris, J. C. and Truck, M. 1996. Antibiotic susceptibility testing by a standardized single disc method. Am. J. Clin. Pathol., 145: 225-230.

Bergan, T. 1984. Methods of Microbiology. Vol. 15. Academic Press INC. (LONDON) Ltd. p. 146.

Bhan, M., Bahl, R. and Bhatnagar, S. 2003. Typhoid and paratyphoid fever. The Lancet, Volume 366, Issue 9487, pp. 749-762. 
Bleich, A., Kirsch, P., Sahly, H., Fahey, J., Smoczek, A., Hedrich, H. and Sundberg, J. P. 2008. klebsiella oxytoca: opportunistic infections in laboratory rodents. Laboratory Animals, 42(3): 369-375.

Buxton, A. and Fraser, G. 1987. Escherichia coli In. Animal Microbiology Blackwell Scientific Publications. Oxford, London, Edinburg, Melbourne. 1, pp. 78-80.

Center for Disease Control and Prevention (CDC) 2001. November. "Typhoid and Paratyphoid Fever." Communicable Disease Management Protocol.

Cheesbrough, M. 1985. Medical Laboratory Manual for Tropical Countries. Vol. II. Microbiology. pp. 248-264.

Chowdhury, M. A., Rahman. K. M., Miah, M. R. and Haq, J. A. 1994. Transferable drug resistant (Rfactor) among the Enterobacteriaceae in urinary tract infections: a study at an urban hospital in Bangladesh. J. Trop. Med. Hyg., 97(3): 161-166.

Cogen, A. L. and Moore, T. A. 1990. $\beta_{2}$-Microglobulin-Dependent Bacterial Clearance and Survival during Murine Klebsiella pneumoniae Bacteremia. Infection and Immunity, 77(1): 360-366.

Cowan, S. T. 1985. Cowan and Steel's manual for identification of medical bacteria. $2^{\text {nd }}$ edn. Cambridge University press, Cambridge, London. pp. 138-139.

Crump, J., Luby, S. P. and Mintz, E. D. 2004. The global burden of typhoid fever. Bull World Health Organ., 82: 346-353.

Freeman, B. A 1985. Burrows Textbook of Microbiology. 22nd edn. W.B. Saunders company, Philadelphila. p. 464-472.

Guthrie, R. 1991. Salmonella- The infection. 41-61. In: Guthrie Rufus. Salmonella. CRC Press, Inc., Boca Raton, Florida.

Jordi, B. J., Boutaga, K., Van Heeswijk, C. M., van Knapen, F. and Lipman, L. J. 1999. Sensitivity of Shiga toxin-producing Escherichia coli (STEC) strains for colicins under different experiment condition. FEMS Microbiol. Lett., 204: 229-234.

Levine M. M. and Kaper, J. B. 1983. New knowledge on the pathogenesis of enteric infections as applied to vaccine development. Microbiol. Rev., 47: 510-550.

McClelland, M., Sanderson, K. E., Clifton, S. W., Latreille, P., Porwollik, S., Sabo, A., Meyer, R., Bieri, T., Ozersky, P., McLellan, M., Harkins, C. R., Wang, C., Nguyen, C., Berghoff, A., Elliott, G., Kohlberg, S., Strong, C., Du, F., Carter, J., Kremizki, C., Layman, D., Leonard, S., Sun, H., Fulton, L., Nash, W., Miner, T., Minx, P., Delehaunty, K., Fronick, C., Magrini, V., Nhan, M., Warren, W., Florea, L., Spieth, J. and Wilson, R. K. 2004. Comparison of genome degradation in Paratyphi A and Typhi, human-restricted serovars of Salmonella enterica that cause typhoid. Nature genetics, 36(12): 1268-1274.

Merchant, I. A. and Packer, R. A. 1967. Veterinary Bacteriology and Virology, $7^{\text {th }}$ edn., The Iowa University Press, Ames, Iowa, USA, pp. 286-306.

Morshed, M. G., Khan, N. Z., Khan, W. A. and Akbar, M. S. 1986. Multiple drug resistant S. Typhi in Bangladesh. J. Diarrhoeal Dis. Res., 4: 241.

Parry, C. M., Karunanayake, L., Coulter, J. B. and Beeching, N. J. 2006. Test for quinolone resistance in typhoid fever. BMJ.,, 333(7561): 260-261.

Rubin, R., David, S., Strayer and Rubin, E. 2007. Jay M. McDonald. Rubin's Pathology. 5th edn.

Ryan, K. J. and Ray, C. G. (editors) (2004). Sherris Medical Microbiology (4th edn.). McGraw Hill. p. 370 . 
Sghau, I. G., Foley, M. K., Scott, E. G. and Bailey, W. R. 1958. Diagnostic bacteriology, A textbook for the isolation and identification of pathogenic bacteria and systemic fungi. $5^{\text {th }}$ edn. pp. 127-128.

Stock, R. and Wiedemann, B. 2001. Natural antibiotic susceptibility of Klebsiella pneumoniae, K. oxytoca, K. planticola, K. ornithinolytica and K. terrigena strains. J. Med. Microbiol., 50: 396-406.

Thomas, A. R., Bruce, A. D., Stacy, A., Genagon, N. M., Warholic, U. M., Patrick, D., Pawlicki, J. M., Beanan, R. O., Bruce, A. H. and Paul, R. K. 2005. Escherichia coli virulence factor hemolysin induces neutrophil apoptosis and necrosis/lysis in vitro and necrosis/lysis and lung injury in a rat pneumonia model. Am. J. Physiol. Lung Cell Mol. Physiol., 289: 207-216.

Wong, S. H., Cullimore, D. R. and Bruce, D. L. 1985. Selective Medium for the Isolation and Enumeration of Klebsiella spp. Applied Environ. Microbiol., 49(4): 1022-1024. 